OPEN ACCESS

Edited by:

Bernardo Mançano Fernandes, São Paulo State University, Brazil

Reviewed by:

Esther Ronner,

Wageningen University and Research, Netherlands

Richard Miro,

Makerere University, Uganda Emmanuel Kouopkwa Njukwe, International Institute of Tropical Agriculture (IITA), Kenya

*Correspondence: Anne M. Rietveld a.rietveld@cgiar.org

Specialty section:

This article was submitted to Social Movements, Institutions and Governance,

a section of the journal Frontiers in Sustainable Food Systems

Received: 09 February 2021

Accepted: 11 October 2021

Published: 25 November 2021

Citation:

Rietveld $A M$ and van der Burg $M$ (2021) Separate and Joint Interests: Understanding Gendered Innovation Processes in Ugandan Farm Systems. Front. Sustain. Food Syst. 5:666051. doi: 10.3389/fsufs.2021.666051

\section{Separate and Joint Interests: Understanding Gendered Innovation Processes in Ugandan Farm Systems}

\author{
Anne M. Rietveld ${ }^{1,2 *}$ and Margreet van der Burg ${ }^{3}$ \\ ${ }^{1}$ The Alliance of Bioversity International and CIAT, Rome, Italy, ${ }^{2}$ Farming Systems Ecology Group, Wageningen University, \\ Wageningen, Netherlands, ${ }^{3}$ Department of Social Sciences, Wageningen University, Wageningen, Netherlands
}

Agricultural innovation is considered paramount in solving poverty, food insecurity and malnutrition in the global south and notably in the East-African highlands. However, processes of change surrounding innovation in agriculture, and potential gender differences in their impacts, are often poorly understood. This paper resorts to principles from Farming Systems Research (FSR) and social gender analysis to study agricultural innovation processes and increase the understanding of the differential ways men and women engage with and are impacted by agricultural innovation(s). We analyze qualitative data from six Focus Group Discussions conducted in each of the two study communities located in Central and Western Uganda. These data focus on the most important agricultural innovations as perceived and assessed by men and women in their community. We list and discuss these most important innovations and further zoom in on one innovation per site: "Use of herbicides in maize production" in Central Uganda and "New agronomic practices for intensified highland banana production" in Western Uganda. Results clearly show that women's and men's domains are not separated as superficially might appear. Women and men have both separate and joint interests and adoption of an innovation by one gender, will affect the other too. The effects are multifold, with positive and negative elements. Women's ability to innovate is constrained as compared to men because gender norms limit women's agency in relation to mobility and financial independence amongst others. The two innovations studied were found to alter some gender roles and relations but did not unambiguously contribute to increasing gender equality.

Keywords: smallholder farming, agricultural innovation, Farming Systems Research, gender, Uganda

\section{INTRODUCTION}

In the East-African highlands, levels of poverty and malnutrition are high (Garrity et al., 2012). Developing new technologies or innovations for increasing agricultural productivity and profitability for smallholder farmers through Agricultural Research for Development (AR4D) is often conceived as essential for alleviating rural poverty and improving food security and nutrition (Doss, 2006; GCARD, 2011; Glover et al., 2019). Agricultural innovation can be defined as "putting an idea into practice for the first time" (Fagerberg et al., 2005 cited in Kawarazuka and Prain, 2019). This idea can be a product (e.g., a fertilizer blend), a technology or practice (e.g., narrow row sowing) but also a way of organizing activities or processes (e.g., bulking produce for collective 
marketing) which changes existing routines and/or resource flows (Cohen et al., 2016). In this article we examine agricultural innovation in two communities in different regions of Uganda in relation to outcomes for women and men using a Farming Systems Research (FSR) approach. First, we discuss literature dealing with adoption of agricultural innovations, innovation processes, the role of gender and relevance of FSR.

\section{Adoption of Agricultural Technologies}

The extent to which technologies and innovations are taken up (or not) by smallholder farmers and are integrated into farming systems tend to be evaluated through "adoption" studies (Glover et al., 2019). The body of literature on technology adoption by smallholder farmers is vast and diverse just as the target audiences/populations and the technologies in question. Agroecological conditions, wealth, gender and other forms of social differentiation often emerge as important factors influencing technology adoption (Knowler and Bradshaw, 2007; Pircher et al., 2013; Addison and Schnurr, 2016). A main critique on adoption studies in general, is that farmers' realities are not (well) captured (Thompson and Scoones, 2009; Pircher et al., 2013; Michalscheck et al., 2018). This can be because awkward assumptions on the perceived superiority of the technology are made (Doss, 2006), the wrong output of a technology is assessed and measured (Michler et al., 2018) and/or heterogeneity of either or both agro-ecological and social-economic factors are not (sufficiently) taken into account (Ndiritu et al., 2014; Addison and Schnurr, 2016; Llewellyn and Brown, 2020). Moreover, what adoption exactly entails, is not well-elaborated in many studies (Addison and Schnurr, 2016; Glover et al., 2019). It is too simplistic, for instance, to present technology adoption as a dichotomy of either adopting or not and as a linear process. The assumption that someone either adopts or not, omits the options that technology might be adapted to local context or partially adopted. Especially when technologies are more complicated and encompass several components, adaptation or partial adoption becomes more likely (Glover et al., 2016; Ronner et al., 2018). Use of newly adopted practices also does not necessarily increase over time as is often assumed but instead dis-adoption, when people cease to use a certain innovation or parts of it, can take place (Doss, 2006; Grabowski et al., 2016; Ronner et al., 2018).

According to Glover et al. (2019) the concept of "adoption study" provides a poor basis for understanding processes and consequences of change in the first place. Not only are the technology and object of the study treated as black box, there is also not enough focus on the process of change which surrounds the "adoption." For instance, adoption studies generally show higher rates of technology adoption for men than for women (Doss, 2001; Petesch et al., 2018a). This gender disparity is commonly attributed to women's lack of access to essential resources and inputs, but we lack more detailed studies on causes, consequences, or impacts of (full, partial or non-) adoption of an innovation which often obscures the actual benefits (or detriments) of technological innovation for (sub-groups of) populations or the environment (Zulu et al., 2020).

\section{Agricultural Innovation and Gender}

The lack of understanding on (1) processes of change surrounding innovation and its adoption by target populations and (2) impact of technology adoption on a farming system and overall population, is especially pertinent in relation to gender. This is because innovation processes are relational and reflect the power and agency of individuals and groups involved, which tend to be highly gendered in smallholder farming systems (Cohen et al., 2016; Badstue et al., 2018a; Kawarazuka and Prain, 2019). Farnworth et al. (2019) elaborate on the difference between men and women (farming) innovators in Ethiopia by explaining that male innovators could challenge norms to some extent because they were allowed to reject the "technical correct way of farming" by proposing alterations. In contrast to female innovators, men did not need to negotiate and navigate intricate social and power relations, because their gender embodied the cultural norm. The social space (between norm and sanction) for women to innovate was more limited than for men (Farnworth et al., 2019) which applies to many contexts in the global South.

Since agricultural innovation is about doing things differently, it is likely to disrupt the ways men and women had been involved in farming (Sørensen, 1996). Because of this, agricultural innovation can also be a purposeful pathway to more gender equality (Padmanabhan, 2007; Badstue et al., 2018a; Petesch et al., 2018d). The opposite is also true; innovation can impact specific gender groups negatively (Bergman-Lodin et al., 2012) and reinforce or even increase existing disparities and inequality (Kansanga et al., 2019) and deprivation. For instance, a mix of positive and negative effects of innovation on gender equality is described by Bullock and Tegbaru (2019) in relation to hybrid maize innovations in Western Kenya. Here, multiple and various decision-making processes, as well as access to assets and resources both increased and restricted development toward more gender equality for specific groups of women. Women experienced, for instance, expanded opportunities to learn about agri-innovations and to put their knowledge to use but continued having limited control over productive assets such as land (Bullock and Tegbaru, 2019).

\section{Farming Systems Research}

In an effort to address gender and agricultural innovation processes more comprehensively we turn to Farming Systems Research (FSR). FSR was developed in the 1970s as a whole farm orientation including an "user" and impact perspective in diagnostics and solutions for farming which especially allowed to serve formerly overlooked groups such as smallholders and women (Bawden, 1996; Norman and Atta-Krah, 2017; van der Burg, 2019). A key starting point of FSR was that only if technology development is "grounded in full knowledge of the existing farming system" (Merrill-Sands, 1986, p. 88) and responds to physical and technical performance and to the needs and wishes plus cultural values of the farmers concerned (MerrillSands, 1986; Darnhofer et al., 2012), it will be considered relevant, used and adapted by farmers.

FSR was considered particularly relevant to address heterogeneity in contexts; both with regards to agro-ecology and environment and to cultural, social and economic dimensions 
(Merrill-Sands, 1986; Darnhofer et al., 2012). It became clear in the 1970s and after, that the successes of the green revolution were not easily replicated in less favorable contexts, such as for instance the East African highlands. As part of a multidisciplinary approach, gender analysis (GA) next to other social analyses was considered as inherently important and common practice in FSR (Poats et al., 1988; Feldstein, 2000; Bingen and Gibbon, 2012; Norman and Atta-Krah, 2017; van der Burg, 2019). Nevertheless, in more recent FSR literature such a wider approach or gender analysis is mostly absent (e.g., in most chapters of the book of Darnhofer et al., 2012). Features of FSR that resonate with a gender analysis include the farmer-oriented approach to technology development and assessment, the inclusion of farmers' voices (Poats et al., 1988; Feldstein, 2000; Stroud and Kirkby, 2000) and the acknowledgment of the diversity of profiles and thus of farmers' needs and opportunities (Collinson, 2000). Gender analysis specifically enables uncovering views and perspectives from others than those belonging to dominant groups (McDougall, 2017). This is integrated within a multi-scale and multi-criteria approach to assess performance, alongside the realization that farmers may compromise on optimal technical performance (Hart, 2000) because of other short and long-term (more pertinent) considerations. A farming system can be studied at different scales ranging from the individual farmer or farm, to a household and to a collective of households or farms e.g., in the form of a community or landscape (Fresco and Westphal, 1988; Poats et al., 1988; Collinson, 2000). Lastly, agricultural innovation is conceived as a co-creation process shaped by plural interactions between farming systems components and the wider socio-economic environment (e.g., markets and policy) which plays out over ecological, economic, social and technological dimensions (Collinson, 2000; Norman and Atta-Krah, 2017).

\section{Research Approach}

Processes of agricultural innovation and adoption are widely covered in AR4D literature and subject to much debate, yet still far from being understood. The atomistic fashion in which many adoption studies are conducted, is an important reason for this. With the objective to better understand agricultural innovation processes we study and compare the ways women and men in two rural communities in Uganda engage and are impacted. Gender is emphasized because it is identified by many authors as being of great influence in shaping innovation processes, and because innovation might provide a pathway to achieving more gender equality. Inspired by FSR, we explore men and women's perceptions on specific agricultural innovation processes in their community and farm and reflect on their impact on multiple outcomes including gender equality. For our analysis we use qualitative data from two case-studies conducted in Uganda.

\section{METHODOLOGY}

\section{Case-Study Sites}

The case-studies were conducted in 2014 and 2015, respectively in two parishes in Uganda in: (1) Kiboga district in the Central region and in (2) Isingiro district in the South-west of the
Western region. In the South-west of Uganda, agriculture is generally more commercially oriented than in the Central region and gender divisions of labor are stricter in the Central region as compared to the South-West according to Addison and Schnurr (2016).

\section{Site 1-Parish in Kiboga District, Central Uganda (Kiboga)}

The selected parish in Central Uganda is situated $3 \mathrm{~km}$ away from a small trading center along the national Kampala-Hoima road nearby the district town Kiboga. The capital Kampala can be reached by bus within a few hours. People from at least five ethnicities (tribes) live in the community. Baganda and Banyakole are in majority with about a third of total population each. The average household consists of husband and wife with their children. A minority of households is polygamous and about $10 \%$ of all households are headed by women. Agriculture is the main occupancy in the community which is characterized as a maize mixed farming system (Garrity et al., 2012). Highland banana and coffee are both important cash crops and off-farm income is important for livelihoods (Rietveld et al., 2020). Land sizes range from small plots of 0.5 acres to about 15 acres. Women tend to access land via their father or husband and commonly rent small plots from larger landowners. Maize, banana and coffee crops are usually controlled by men in this site, although women can also have (small) banana plantations of their own. Beans are an important crop for women. Often, these and other crops such as sweet potato are all intercropped, although maize can also and increasingly be found in single stands. Most available jobs in the community are related to agriculture, with farming (on own farm and/or as casual laborer) being the most prevalent for both men and women. Trading in agricultural goods is important for men. Few people in the community have legal land titles; most are tenants. Men usually rent much larger plots than women. Saving/credit and religious groups are important and most people in the community are members of such groups.

\section{Site 2-Parish in Isingiro District, Western Uganda (Isingiro)}

The selected parish is located in Isingiro district in Western Uganda. Isingiro district is bordering Tanzania and houses several large refugee settlements/camps with notably Nakivale refugee camp nearby. The city of Mbarara, a trading hub for highland banana and an intersection for national roads, is on $2-3 \mathrm{~h}$ drive. The most common ethnicity with about $75 \%$ is the Banyankole but six other ethnicities live in the community. About $25 \%$ of households are headed by a woman and about $1 / 3$ of households is polygamous. Most households are smallholders with on average 2 acres of land. $\sim 30 \%$ households are large landowners with land sizes up to 200 acres, and $10 \%$ of the population is landless. Few women own land and those who do, own smaller plots of around 0.75 acre. Sharecropping and renting of land is common among women. The farming system is characterized as highland perennial farming (Garrity et al., 2012). Agriculture occupies the large majority of the population and is dominantly focused on the commercial cultivation of highland banana as monocrop which is controlled by men. Other 
important crops include maize, beans, sweet potato and millet which are all cultivated mainly as food-crop and tend to be controlled by women. Cattle keeping is important in the area but reducing in volume; some farmers own cattle which is (partially) grazed in other communities; others keep their cattle closer-by, but a complete zero-grazing regime is rare.

\section{Methods and Tools}

For a social gender analysis of agricultural innovations in line with the principles of FSR we resorted to a methodology which relates agricultural innovations to assessments of women and men community members. Such research methodology was developed within the GENNOVATE project (https://gennovate. org/). This project set out to study the relation between agricultural innovation and gender norms. Its methodology and conceptual framework are described in detail in Badstue et al. (2018b) and Petesch et al. (2018a).

For this paper, a sub-set of data collected in two GENNOVATE case-studies was used. The two case-studies were analyzed using $\mathrm{N}$ vivo software version 10 (initially) and 12 (eventually) for qualitative data analysis.

The data were collected in six Focus Group Discussions (FGDs) for each case study (three with men, three with women). The FGDs were held separately with adult men and women, of either poor or middle wealth status, and with young men and women as set by the GENNOVATE method guide (Table 1). For our analysis we only used data on topics similarly addressed in all FGDs. Case-study participants were selected with support from a community-based "mobilizer." FGDs were facilitated by a field data-collection team member of the same sex as the participants. Documentation of the FGD was conducted by a second person (of the same sex as the FGD participants) through notetaking. All field data-collection team members received training prior to going to the field.

In every FGD, participants were asked to list the main innovations in agriculture and natural resource management (NRM) that they themselves applied or were introduced to in the past 10 years. After this, participants jointly picked a top two of "most important innovations" for men and for women in their community which they discussed further.

\section{RESULTS}

\section{Important Innovations in Agriculture and NRM \\ Kiboga Innovations}

Most of the innovations mentioned (Figure 1), were directly related to crop cultivation or animal production. Only two innovations referred to socio-organizational or "soft" innovations: (1) "Creation of Saving and Credit Cooperation's (SACCO)" and (2) "Women's production orientation for both food and sales". A SACCO allows paying members to take out loans for various purposes, for instance to pay agri-inputs or school fees.

The local SACCOs handled relatively small amounts of capital; savings per person per week varied between 0.6 and 3 USD per week ( 1 USD $\approx 3,300$ UGX in 2017) and loans had to be
TABLE 1 | Overview of details of the three different FGDs (Petesch et al., 2018b).

\begin{tabular}{ll} 
FDGs & Differentiation by age and wealth \\
\hline $\begin{array}{l}\text { FGD C: MALE (men) and FEMALE } \\
\text { (women) }\end{array}$ & $\begin{array}{l}\text { Age: } 30-55 \text { years old wealth group: } \\
\text { poor }\end{array}$ \\
$\begin{array}{l}\text { FGD D: MALE (men) and FEMALE } \\
\text { (women) }\end{array}$ & $\begin{array}{l}\text { Age: } 25-55 \text { years old wealth group: } \\
\text { middle }\end{array}$ \\
$\begin{array}{ll}\text { FGD E: MALE (men) and FEMALE } \\
\text { (women) }\end{array}$ & Age: 16-24 years old \\
\end{tabular}

repaid within 2 months with $20 \%$ interest. The innovation of "Women's production orientation for both food and sales" referred to the trend of women increasingly engaging with economic or "productive" activities next to their household or "reproductive" roles. Women's farming used to be focused on home consumption only but has become more commercially oriented as women sell (surplus) farm produce and control the thus derived income.

"Herbicides" and "Improved maize" were listed most often, mostly by men or by women "for men". Both innovations were not formally introduced nor promoted by external organizations but rather became available on the market through input suppliers. The two innovations are inter-linked since the "herbicides" were primarily used for maize and we will henceforth refer to this innovation as "herbicide use in maize production". Women explained that spraying of herbicides had greatly reduced the need for weeding, which led to both a reduction in their workload but also in an increase of land under maize cultivation. "Now men grow acres and acres of maize" said women in FGD C-Females.

Some of the innovations listed were elements of an integrated mixed farming approach promoted by a research for development project which ran in the Kiboga site from 2010 to 2014. This project promoted zero-grazing of goats (improved breeds), fodder production in and around banana plantations, (goat) manure application on banana; with planting and during growth and new banana cultivars. In one FGD (C-Females) women listed an innovation for men as important, which was not mentioned by men at all namely: "New cash crops; tomatoes, vegetables and fruits". Men on their turn, considered "Improved beans" (varieties) as important to women, whereas women had not mentioned it.

\section{Isingiro Innovations}

In Isingiro, only "hard" innovations related to crop and animal production were listed (Figure 2). Both men and women consistently ranked "New (agronomic) practices for intensified banana production" as number 1 or 2 of most important innovations for men. In addition, "Control BXW" (control of the banana crop disease Xanthomonas Wilt) and "Zero-Grazing cattle" were listed by and for men as important. The innovations listed by women and men for women were more diverse; apart from cattle and banana-related innovations, innovations related to beans, maize, sweet potatoes, vegetables and chicken rearing were listed. These were each mentioned in only one FGD. Men 


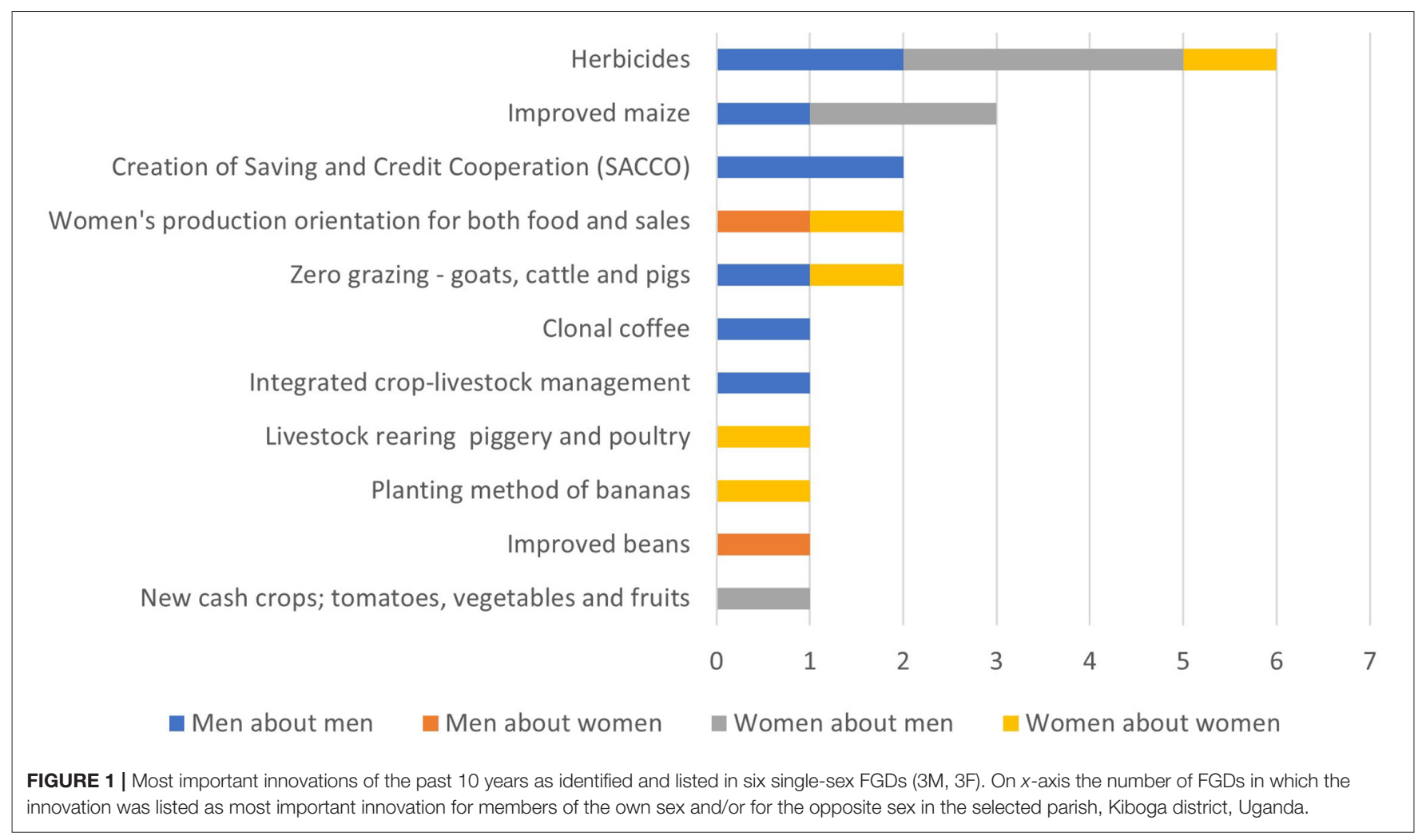

mentioned "growing vegetables," "growing orange-flesh sweet potato" as important to women, but women themselves did not mention these.

\section{Herbicide Use in Maize Production in Kiboga}

The agricultural innovation most consistently mentioned by women and men in Kiboga was "herbicide use in maize production". From the data, further presented below, it became clear that disparities, related to the access, use and benefits derived from herbicide use in maize production, existed both between and within households, and that these were related to gender norms which prescribe how men and women should behave.

\section{Who Uses the Innovation, Who Not and Why?}

According to young men (FGD E-Male) everyone used herbicides in maize production at the time of the FGD, but adult men and women and young women nuanced this by saying that herbicides were mostly accessible to men (FGD C-Female). A few women in the FGD D-Females also mentioned using herbicides to clear land for bean cultivation. The costs attached to using this innovation limited poorer people from using it including young men and women who might live in wealthier households but cannot access financing (FGD E-Female; FGD C-Male). But for women, additional gender specific reasons were provided to explain why they hardly used herbicides in farming. These reasons were mostly not specific to herbicide use but also applied to the use of other agri-inputs. Young women emphasized for instance that all "new" practices required some money, which they did not have access to. Apart from money, women had limited time and ability to actually purchase the inputs. Since inputs such as herbicides are mostly sold in trading centers, buying them requires travel. Not only did women often not have the time to travel, nor the money for transport, it was also normatively contested for women to travel outside or (too much) inside of the community alone. "Women who move around; they call them prostitutes" was explained in one FGD (C-Female). A more general reason why women hardly used herbicides was that its use is primarily associated with maize production which was mainly conducted by men.

\section{Who Benefits From the Innovation, Who Not and How?}

In the study site, men and women generally cultivated their own plots although men usually owned the land and choose which plots to allocate to their spouse(s). The plots allocated to women tended to be much smaller and production was oriented toward home-consumption. Where men focused on coffee, banana and maize as key-crops on their plots, women produced mainly beans and root and tuber crops on theirs. Men (FGD C\&D-Males) stated that using herbicides in maize production had enabled them to increase acreage under maize which had resulted in higher yields and therefore improved household food security and availability of feed (maize bran) for animals. Young men (FGD E-males) emphasized how use of herbicides had enabled farmers to gain a lot of money from maize production. The 
New practices for intensified banana production

\section{Zero-grazing cattle \\ Control BXW: Complete Mat Uprootal}

Good management of beans and maize

Growing orange-flesh sweet potatoes

Growing vegetables

New bean varieties

New maize varieties

Rearing chicken in enclosures
0
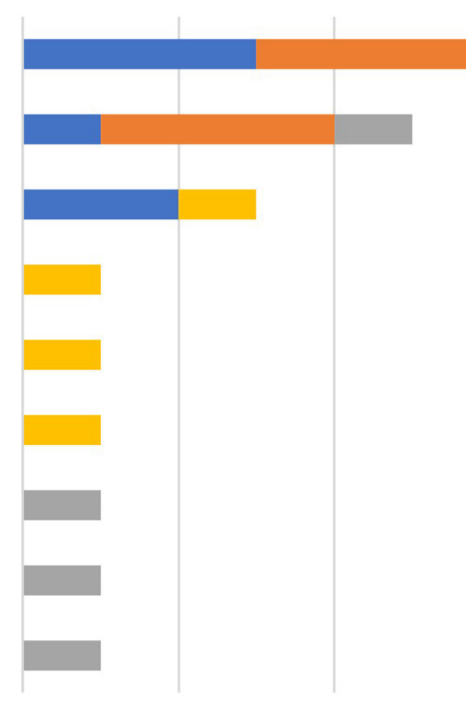

2

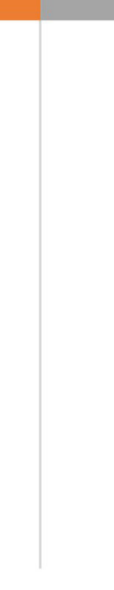

4

Women about women

Women about men
Men about men

FIGURE 2 | Most important innovations of the past 10 years as identified and listed in six single-sex FGDs (3M, 3F). On $x$-axis the number of FGDs in which the innovation was listed as most important innovation for members of the own sex and/or for the opposite sex in the selected parish, Isingiro district, Uganda.

pathways through which women benefitted or not from "use of herbicides in maize production" were less straightforward.

Women did provide labor to the husbands' plot(s) next to their own plot and were also expected to prioritize their husband's plot; "The men demand that you work on their farms first before you work on yours and you must go to their farms in the morning when you are still fresh so the only time that you have for your own crops is in the evening when you are already tired" (FGD C-Females). Since women were responsible for weeding amongst other tasks, their labor availability was limiting maize production before the use of herbicides was common practice. Consequently, the use of herbicides reduced the demand on women's labor for weeding (applying herbicides was commonly performed by men) and as such the innovation benefitted them. Women narrated diverting their labor to other livelihood activities still mostly in the agricultural domain. The economic or commercial orientation of their activities was new. This was also listed as an innovation in itself; "Women's production orientation for both food and sales" in both a male and female FGD (C-Males and C-Females), (Figure 1). The opportunities for women to earn an income from sales of agricultural products or from casual farm labor generally increased. "We were not allowed to work 10 years ago. Today, we can farm separate plots and earn an income" (FGD D-Females). This development was the result of changes in gender norms around women's economic participation (which can be observed throughout the global South, e.g., Petesch et al., 2018c,d; Bullock and Tegbaru, 2019) and in the local agricultural economy notably increased market-access and-connectedness, next to herbicides reducing women's workload. While women's ability and space to earn money expanded, it was also still contested, and this reflected back on maize production using innovations such as herbicides. Women (FGD C-Females) indicated that not all women in the community were able to work for money (yet), and that it was highly dependent on the husband's attitude. Some women mentioned they would like to grow maize (commercially) but that men generally opposed this (FGD D-Females). Apart from the difficulty they experienced in accessing information and funds to buy inputs, selling of produced maize was also a problem. They were often obliged to act via their husbands when they wanted to sell maize or any other produce because women could not travel to the market as easily as men. A lack of (appropriate) transport was provided as reason: "A woman cannot go along with her produce on top of a lorry!” (FGD DFemales). Opinions were divided as to whether it was good or not to sell produce through one's husband. Some women mentioned advantages as men being better informed about prices and therefore less likely to be cheated by traders. Others argued that some men only give part of the revenue to their wife and keep the rest for themselves. Men mostly preferred to be engaged in the sales efforts of their wives and some even considered this as a condition for allowing their wife to sell produce; "he may allow her [to sell agri-produce] because he will be able to know how much she earns and accordingly he will plan for its use/spending" (FGD E-Males).

Women, as wives and daughters of the men in their households, were frequently benefitting from outcomes such as increased yield and income from maize, both in terms of improved food security and specific investments (mostly school fees for children) which benefitted the household at large. But women also narrated a scenario through which women did not 
benefit from the husband's increased income from maize. In this scenario men left responsibilities that used to be in their (male) domain, such as paying school fees for children, up to women; "A good number of men are not taking care of their homes, so you have to pay school fees, pay hospital bills and feed the children (FGD D-Females).

It was mentioned in the FGDs that for a part of the farming population, mostly wealthier men with a certain level of access to resources, there was a linear pathway via maize yield increases and expansion of area under maize to increased income from maize and thus to development outcomes such as improved food security and reduced poverty. We observed that these benefits did not always trickle down to the whole household however. While use of herbicides in maize production reduced women's workload in weeding, and therewith increased their ability to engage in other economic activities, the local normative climate was still characterized by deep entrenched prejudice against "working women" and "women with money." "Men are afraid she will grow wings" young women said in response to statements around women earning money (FGD E-Females), meaning that she would not be subservient (enough) to her husband anymore once she would have money of her own. It was generally stated that men's status as head of the household would be threatened if their wife would make money: "women become stubborn when they get money; they can never respect their husbands again" (FGD E-Males). In addition, the anticipated improved financial status of women was associated with more mobility and (thus) promiscuity: "if you give her a chance to look for money, she will 1 day disappear with other men" (FGD E-Males). The responses of male youth on the topic of "working women" were more stringent and disapproving than those of adult men in general. Similarly, female youth were more outspoken about the limitations they faced then adult women were, young women also seemed more restricted in their mobility compared to older women, for instance when it came to "moving around in the village."

\section{New Agronomic Practices for Intensified Banana Production in Isingiro}

The new agronomic practices for intensified production of highland banana in Isingiro included use of manure; desuckering or removing corms; spacing; hand-weeding, trench digging (for water retention) and mulching. These laborintensive practices resulted in both the production of larger bunches and thus in more commercial potential as the market favored large bunches and in higher productivity. "BXW control" was about controlling the disease and curtailing banana production losses. In this way, it was related to the first mentioned innovation as both were geared toward optimizing highland banana production and sales.

\section{Who Uses the Innovation, Who Not and Why?}

All these practices were introduced through a de-centralized governmental extension program that promoted commercial farming in the district from 2004 onwards. Some of these practices (e.g., de-suckering; digging trenches) require a lot of physical strength and this was provided as a reason why these were almost exclusively performed by men.

Both men and women indicated that banana plantations were controlled by men "Most plantations are owned by men and the bananas are main source of income, so the men's interest is there" (FGD C-Females). Owning a banana plantation determined man's status in the community. A "good farmer" or even "good husband" owned a banana plantation by definition. A "good wife" was described as someone who assists her husband with banana management, notably with weeding by hand. The only category of women who owned banana plantations in the community were widows; they were able to sell banana independently. Some widows, if they could not afford to hire labor, also applied the new agronomic practices such as de-suckering themselves.

\section{Who Benefits From the Innovation, Who Not and How?}

There was a wide consensus in Isingiro that the "new agronomic practices for intensified banana production" and resulting increases in production and income from banana sales had a large impact on livelihoods in the community. Banana stood out as the most important source of income for the majority of male farmers and for the households in the community as a whole. It is not surprising therefore that women also mentioned these banana-related innovations as paramount; banana was the main source of household food and income. The community leaders praised the community as follows "people in this parish have constructed good houses compared to other parishes. In addition, the parents here try to educate their children" and "many people have become rich because of the highland banana." One of the new agronomic practices was weeding by hand without using tools to avoid damaging the shallow banana roots. This negatively impacted women as wives of men with small or middle-size landholdings because they were responsible for weeding; not only was it (more) time-consuming, but it also involved a lot more bending which caused women back pain. Women also mentioned that children were regularly required to assist with weeding when weed pressure was high and consequently missed school (FGD-C Females). Wives of the wealthiest farmers who were less represented in our study, were allegedly less hindered by this as their husbands relied on hiring labor for banana plantation management including weeding. This on its turn, created more opportunity for women from less resource-endowed households to earn money as casual laborer. Especially for poorer women such work became a main source of income over which they had more control than for instance income from food crop sales produced on their husband's land. At the same time, casual work on other people's farm, especially by married women, was still considered as unfavorable for the development of the own household by most in the community and therefore a topic of negotiation between spouses.

With men focused on banana, women gained more opportunity to grow other annual crops: "10 years ago, the seasonal crops that were grown were the only source of income and they were controlled by men but now men are on bananas and women can get some income from the seasonal crops" (FGD C-F). However, getting access to land for women was problematic 
because land was predominantly owned by men. Some men gave their wife a plot to cultivate, other women resorted to renting land. The availability of cropping land had decreased rapidly though as more and more land was brought under banana mono-cropping. As a result, land rent prices increased (FGD C-Females and males).

The commercial production of highland banana using the new management practices caused revolutionary changes in many people's livelihoods, especially for those with large land holdings; their rising income enabled them to raise their standard of living significantly with larger and better built houses for instance, and by accessing better and higher education for children. Fewer households lived under the poverty-line, as defined by the community itself, and a new class of "super-rich" emerged. This also led to increasing wealth differences amongst households in the area. These "new" rich farmers had access to sparse resources such as land and manure, owned vehicles and trucks, kept on expanding their plantations, and often employed dozens of farm laborers. This was in stark contrast with the landless or smallholders owning $<1$ acre who "don't have anything of their own" (FGD C-Males). Their only option was to "work for the rich" to earn in cash or kind. Being knowledgeable about new agronomic practices for intensified banana production helped them to get more work "because the rich also want to use those who are good" (FGD C-Females).

The commercial production of highland banana using the new agronomic practices boosted the local economy. The large majority of the parish (male/female, poor/rich, young/old) benefitted to some extent from this development in terms of increased income. The valuable banana plantations however were firmly controlled by men and the gender division of labor for banana practices remained strict, the only exception to the rule seemingly for widows. This was most evident when it came to harvesting and sales; this was generally performed by men. With men's increased focus on banana production, some space was created for women to earn money through cultivation of annual crops but women's access to inputs and land remained limited. Moreover, women, especially those married to men owning middle-large plantations, spend a lot more time working in their husband's banana plantation. In addition, married women had less ability than their husbands to mobilize labor from other household members, such as children, as they could not "dictate," and they also generally lacked the resources to hire external labor. As such, no consolidated advances through the innovation in banana production were made regarding gender equality. Regarding other outcomes such as increased income, outcomes differed depending mostly on land-ownership and size of land owned.

\section{DISCUSSION}

We explored men's and women's perceptions and assessments around changes and opportunities by agricultural innovation in their community and farm and we particularly focused on innovations identified as "most important" by men and women themselves.
From our analysis, gender appeared to be key for understanding both the innovation processes and the impact of certain innovations on rural populations and environment. In both case studies, divisions of labor were very gendered though under pressing circumstances, especially among poor farmers and toward widows, boundaries seemed to have become more fluid, heterogeneous and negotiable. Yet the types of crops cultivated, the practices used, and the associated socio-economic dynamics proved important for defining men's and women's gender identities (c.f., Padmanabhan, 2007). Banana sales and income were strictly controlled by men in Isingiro and owning a banana plantation was an important indicator of success and status for men in the community. Nevertheless, women spent most of their time working on this crop and emphasized that derived revenues benefitted the household at large. Calling highland banana a "men's crop" is not useful under these conditions, since it ignores the central role this crop plays for both women and men, and the investment both make in terms of finance or labor inputs. It is rather as Meinzen-Dick et al. (2012) argue that boundaries between so-called men and women's crops proved being less rigid than they initially appear. The same accounts for labeling farm plots as women's or men's; even as women often have their own plot to cultivate, the land is still owned by the husband or rented from another man. Or the revenue from the produce is managed, at least partially, by the husband, and he is consulted and gives permission on which crops to plant or what inputs to use. Taking the whole farming system and activities of all members in account thus allowed to conclude that for both case studies there is no complete gender separation of crops or plots, according to what is observed elsewhere in the region (Lambrecht et al., 2016; Rietveld and Farnworth, 2018). It implies that it is not fruitful to assume a strict separation of gender interests when there is a rather clear gender division of labor. It is important to realize, in the words of Okali (2011, p. 2) "that women and men as household members may have both separate and joint interests while remaining engaged in what is essentially a cooperative enterprise."

Despite these joint interests, we uncovered that women's agency and their capacity to innovate is often constrained in these communities. First, for instance, when it comes to economic activity: "earning an income" or "having money" is perceived as part of men's identities and not of those of women. By including socio-cultural values as influencing farming systems we learnt that shared norms prescribe that men should be the ones earning an (the main) income in a household and be the main decision-maker on income and expenditure. Other scenarios were believed to lead to spousal conflicts as it was expected that a woman, irrespective of her or the households' wealth status, would not accept the authority of a man when she brings in more money than him. Secondly, the stigma that lies on women who move around a lot, inside but especially outside the community, effectively kept women from employing activities outside of the homestead and the community. Since these norms clearly affected women's ability to innovate compared to men as found elsewhere as well (Badstue et al., 2018a; Farnworth et al., 2019), women remained in this condition which was reinforced 
because men controlled most productive assets such as land, and transport means.

We focused on the innovations most often mentioned by men and women themselves and it is not surprising that for the two highest ranked innovations ("herbicide use in maize production" in Kiboga and "new practices for intensive banana production" in Isingiro) the innovation process was mostly geared by men; and that the subject of these innovation processes was normatively associated with men's identity as farmer. One could even argue that agricultural innovation itself, is more associated with men's gender identity than it is with women's as men are considered as "main" farmers both by themselves and by external support structures such as research and extension services (Farnworth et al., 2019). This does not imply that women did not or cannot innovate in agriculture, but it does mean that the support from their husband is more important than vice versa, a finding which is also confirmed in other GENNOVATE project analyses (Badstue et al., 2018a). We heard several accounts in which men and women deviated from the constraining norms and especially in Kiboga, traditional gender norms seemed to be changing, especially among poor farmers and toward widows, for instance concerning freedom of mobility and women earning money,. The fact that "Women's production orientation for both food and sales" was listed there as an important innovation also illustrates this. It made us think differently about what innovation means; it is not only about putting a new idea into practice for the first time, in a specific place. Innovation can apparently also mean that an idea which is practiced already in a specific locality is newly practiced "by a specific social group" such as women (Tilmar, 2016). This is quite a different approach to thinking about adoption of agricultural innovations compared to, for instance, Rogers (2003) renowned theory on early adopters of agricultural innovation and laggards.

Gender norms and roles are not static (Okali, 2011; Petesch et al., 2018c). Not only do gender norms change over time, the urgency to permit change or reinforcement can also vary for different kinds of social heterogeneity among women and among men. As importantly decisive we found was their wealth status; poor women were, for instance, newly tolerated by their husband to work on other people's farm, out of necessity. Another denominator we can restate is marital status, as we learnt that widows have more space to maneuver around certain norms such as related to the gendered division of labor or land ownership, than married women as also argued by other authors (Badstue et al., 2018a; Petesch et al., 2018c; Farnworth et al., 2019). But also married women negotiated (more) access to land or increased mobility at times, which seemed to be more likely growing with age, e.g., for mature couples with older children. Young women, mostly married women and with small children seemed to be most restricted in their gendered roles in our two cases which is also stated elsewhere (Elias et al., 2018; Petesch et al., 2018c; Rietveld et al., 2020). Not only did they spend more time on caring, but there was also a tendency among male participants of the FGDs, to picture them as promiscuous and not loyal and as such in need of being controlled. Apart from age, number and ages of children and marital status, there are other factors such as personal preference that interact with gender norms and determine the heterogeneous social behavior of women and men.

The innovations studied did not clearly contribute to increasing gender inequality nor the opposite. But both did play an undeniable role in altering the complex dynamics of the gender normative climate influencing women and men's behavior in relation to farming and agricultural innovation. We consider the thought that one innovation can transform gender relations or norms an illusion. But that innovation does influence gender roles and relations was proven unambiguously in our two case-studies.

Applying a FSR perspective enabled us to broaden the study of agricultural innovation with a social and gender analysis in a multiple-faceted way and include a perspective through the eyes of men and women on the complexities around farming. This complexity entails, for instance, that outcomes from innovation processes are not only often multifold but also different among all engaged in farming in even one community. Examining both women and men's roles in a farming system can thus also shed light on certain aspects of diversified adoption or adaption that otherwise remain hidden. This can be very specifically, for instance, related to norms that underlie gender-specific constraints to accessing information in a locality. But it can also enable to identify different, often contradicting, trends and developments that constrain, promote or enable agricultural innovation at a larger level. Including the social realities of men and women farmers on local levels and examining how these relate to larger level trends such as coverage of mobile phone networks or urban demand for specific a crop is important. It will result in having actors working in agricultural R4D, development or policy, better equipped to design innovations, programs and policy meeting development outcomes in agricultural production without compromising the advancement of social and gender equality.

\section{CONCLUSIONS}

We studied agricultural innovation processes in two case-studies in Uganda and particularly the differential roles of women and men in these processes and how they were impacted in terms of development outcomes. We found that although women and men within a household often manage distinct enterprises, this is seldom without any involvement of the other spouse. The two main innovations elaborated on, i.e., the "use of herbicides in maize production" in the Kiboga studysite and "new agronomic practices for intensified production of banana" in the Isingiro study-site, showed that adoption of an innovation by men will affect other household members, notably the farm women, too. Household income and women's workloads were, for instance, affected in both instances. As was shown for both innovations as well; outcomes can be multifold and simultaneously include positive and negative aspects. Gender norms were found to constrain specifically women from engaging in innovation processes, for instance, 
because they limit women's mobility and control over household resources. The two innovations studied were found to alter some gender roles and relations but did not unambiguously contribute to increasing gender equality.

\section{DATA AVAILABILITY STATEMENT}

The raw data supporting the conclusions of this article will be made available by the authors, without undue reservation.

\section{ETHICS STATEMENT}

Ethical review and approval was not required for the study on human participants in accordance with the local legislation and institutional requirements. Written informed consent for

\section{REFERENCES}

Addison, L., and Schnurr, M. (2016). Growing burdens? Disease-resistant genetically modified bananas and the potential gendered implications for labor in Uganda. J. Agric. Hum. Values 33, 967-978. doi: 10.1007/s10460-0159655-2

Badstue, L., Lopez, D. E., Umantseva, A., Williams, G., Elias, M., Farnworth, C. R., et al. (2018a). What Drives Capacity to Innovate? Insights from Rural Women and Men in Africa, Asia, and Latin America, GENNOVATE Special Issue. Gender, Agriculture and Food Security.

Badstue, L., Petesch, P., Feldman, S., Prain, G., Elias, M., and Kantor, P. (2018b). Qualitative, comparative, and collaborative research at large scale: an introduction to GENNOVATE. J. Gend. Agric. Food Secur. 3, 1-27. doi: 10.19268/JGAFS.312018.1

Bawden, R. J. (1996). On the systems dimension of FSR. J. Agric. Educ. Ext. 5, 1-18.

Bergman-Lodin, J., Paulson, S., and Mugenyi, M. S. (2012). New seeds, gender norms and labor dynamics in Hoima District, Uganda. J. East Afr. Stud. 6, 405-422. doi: 10.1080/17531055.2012.696889

Bingen, J., and Gibbon, D. (2012). "Chapter 3: early farming systems research and extension experience in Africa and possible relevance for FSR in Europe," in Farming Systems Research into the 21st Century. The New Dynamic, eds I. Darnhofer, D. Gibbon, and B. Dedieu (Berlin: Springer), 49-71. doi: 10.1007/978-94-007-4503-2_3

Bullock, R., and Tegbaru, A. (2019). Women's agency in changing contexts: a case study of innovation processes in Western Kenya. Geoforum 105, 78-88. doi: 10.1016/j.geoforum.2019.07.007

Cohen, P. J., Lawless, S., Dyer, M., Morgan, M., Saeni, E., Teioli, H., et al. (2016). Understanding adaptive capacity and capacity to innovate in socialecological systems: applying a gender lens. Ambio 45(Suppl. 3), 309-321. doi: 10.1007/s13280-016-0831-4

Collinson, M. (2000). "3.2 evolving typologies for agricultural R\&D," in FSR-Understanding Farming Systems, ed M. Collinson (Wallingford: CABI Publishing), 432.

Darnhofer, I., Gibbon, D., and Dedieu, B. (2012). "Chapter 1: farming systems research: an approach to inquiry," in Farming Systems Research into the 21st CenturyThe New Dynamic, eds I. Darnhofer, D. Gibbon, and B. Dedieu (Berlin: Springer), 3-31. doi: 10.1007/978-94-007-4503-2_1

Doss, C. R. (2001). Designing agricultural technology for African women farmers: lessons from 25 years of experience. World Dev. 29, 2075-2092. doi: $10.1016 /$ S0305-750X(01)00088-2

Doss, C. R. (2006). Analyzing technology adoption using microstudies: limitations, challenges, and opportunities for improvement. Agri. Econ. 34, 207-219. doi: 10.1111/j.1574-0864.2006.00119.x

Elias, M., Mudege, N., Lopez, D. E., Najjar, D., Kandiwa, V., Luis, J., et al. (2018). Gendered aspirations and occupations among rural youth, in agriculture and beyond: a cross-regional perspective. J. Gend. Agric. Food Secur. 3, 82-107. doi: 10.19268/JGAFS.312018.4 participation was not required for this study in accordance with the national legislation and the institutional requirements.

\section{AUTHOR CONTRIBUTIONS}

AR contributed to conception, design of the study, organized the database, conducted analysis, and wrote the first draft of the manuscript. $\mathrm{MB}$ wrote sections of the manuscript. Both authors contributed to manuscript revision, read, and approved the submitted version.

\section{FUNDING}

This study, including the open access publication fee, was funded by the CGIAR Research Program on Roots, Tubers and Banana.

Fagerberg, J., Mowery, D. C., and Nelson, R. R. (eds.) (2005). The Oxford Handbook of Innovation. Oxford University Press.

Farnworth, C. R., López, D. E., Badstue, L., Hailemariam, M., and Abeyo, B. G. (2019). Gender and agricultural innovation in Oromia region, Ethiopia: from innovator to tempered radical. Gend. Technol. Dev. 22, 222-245. doi: 10.1080/09718524.2018.1557315

Feldstein, H. S. (2000). "Gender analysis: making women visible and improving social analysis," in A History of Farm Systems Research, ed M. Collinson (Wallingford: CABI), 67-76.

Fresco, L. O., and Westphal, E. (1988). A hierarchical classification of farm systems. Exp. Agric. 24, 399-419. doi: 10.1017/S0014479700100146

Garrity, D., Dixon, J., and Boffa, J. (2012). Understanding African Farming Systems; Science and Policy Implications. AICAR.

GCARD (2011). The GCARD Road Map Transforming Agricultural Research for Development (AR4D) Systems for Global Impact. Global Forum on Agricultural Research (GFAR). Available online at: https://www.gfar.net/sites/default/files/ EnglishGCARD\%20Road\%20Map.compressed.pdf

Glover, D., Sumberg, J., and Andersson, J. A. (2016). The adoption problem; or why we still understand so little about technological change in African agriculture. Outlook Agri. 45, 3-6. doi: 10.5367/oa.2016.0235

Glover, D., Sumberg, J., Ton, G., Andersson, J., and Badstue, L. (2019). Rethinking technological change in smallholder agriculture. Outlook Agri. 48, 169-180. doi: 10.1177/0030727019864978

Grabowski, P. P., Kerr, J. M., Haggblade, S., and Kabwe, S. (2016). Determinants of adoption and disadoption of minimum tillage by cotton farmers in eastern Zambia. Agri. Ecosyst. Environ. 231, 54-67. doi: 10.1016/j.agee.2016.06.027

Hart, R. (2000). “3.1 FSR's expanding conceptual framework," in FSRUnderstanding Farming Systems, ed M. Collinson (Wallingford: CABI publishing), 432. doi: 10.1079/9780851994055.0041

Kansanga, M. M., Antabe, R., Sano, Y., Mason-Renton, S., and Luginaah, I. (2019). A feminist political ecology of agricultural mechanization and evolving gendered on-farm labor dynamics in northern Ghana. Gend. Technol. Dev. 23, 207-233. doi: 10.1080/09718524.2019.1687799

Kawarazuka, N., and Prain, G. (2019). Gendered processes of agricultural innovation in the northern uplands of Vietnam. Int. J. Gend. Entrepreneursh. 11, 210-226. doi: 10.1108/IJGE-04-2019-0087

Knowler, D., and Bradshaw, B. (2007). Farmers' adoption of conservation agriculture: a review and synthesis of recent research. Food Policy 32, 25-48. doi: 10.1016/j.foodpol.2006.01.003

Lambrecht, I., Vanlauwe, B., and Maertens, M. (2016). Agricultural extension in eastern democratic Republic of Congo: does gender matter? Eur. Rev. Agric. Econ. 43, 1-33. doi: 10.1093/erae/jbv039

Llewellyn, R. S., and Brown, B. (2020). Predicting adoption of innovations by farmers: what is different in smallholder agriculture? Appl. Econ. Perspect. Policy 42, 100-112. doi: 10.1002/aepp.13012

McDougall, C. (2017). "Gender and systems research, leveraging change. Chapter 19," in Sustainable Intensification in Smallholder Agriculture; An Integrated 
Systems Research Approach, eds I. Oborn, B. VanLauwe, M. Phillips, R. Thomas, W. Brooijmans, and K. Atta-Krah (London: Earthscan), 275-288.

Meinzen-Dick, R., van Koppen, B., Behrman, J., Karelina, Z., Akamandisa, V., Hope, L., et al. (2012). Putting Gender on the Map; Methods for Mapping Gendered Farm Management Systems in Sub-Saharan Africa. IFPRI.

Merrill-Sands, M. (1986). Farming systems research: clarification of terms and concepts. Expl. Agric. 22, 87-104. doi: 10.1017/\$00144797000 14174

Michalscheck, M., Groot, J. C. J., Kotu, B., Hoeschle-Zeledon, I., Kuivanen, K., Descheemaeker, K., et al. (2018). Model results vs. farmers' realities. Operationalizing diversity within and among smallholder farm systems for a nuanced impact assessment of technology packages. Agric. Syst. 162, 164-178. doi: $10.1016 /$ j.agsy.2018.01.028

Michler, J. D., Tjernstro, E. M., Verkaart s. and Mausch, K. (2018). Money matters: the role of yields and profits in agricultural technology adoption. Amer. J. Agr. Econ. 101, 710-731. doi: 10.1093/ajae/aay050

Ndiritu, S. W., Kassie, M., and Shiferaw, B. (2014). Are there systematic gender differences in the adoption of sustainable agricultural intensification practices? Evidence from Kenya. Food Policy 49, 117-127. doi: 10.1016/j.foodpol.2014.06.010

Norman, D., and Atta-Krah, K. (2017). "Systems research for agricultural development: past, present and future. Chapter 2," in Sustainable Intensification in Smallholder Agriculture; An Integrated Systems Research Approach, eds I. Oborn, B. VanLauwe, M. Phillips, R. Thomas, W. Brooijmans, and K. Atta-Krah (London: Earthscan), 19-42. doi: 10.4324/978131561 $8791-2$

Okali, C. (2011). "Achieving transformative change for rural women's empowerment," in Proceedings of the Enabling Rural Women's Economic Empowerment: Institutions, Opportunities and Participation (Accra).

Padmanabhan, P. A. (2007). The making and unmaking of gendered crops in northern Ghana. Singap. J. Trop. Geogr. 28, 57-70. doi: 10.1111/j.1467-9493.2006.00276.x

Petesch, P., Badstue, L., Camfield, L., Feldman, S., Prain, G., and Kantor, P. (2018a). Qualitative, comparative, and collaborative research at large scale: the GENNOVATE field methodology. J. Gend. Agric. Food Secur. 3, 28-53. doi: 10.22004/ag.econ.293587

Petesch, P., Badstue, L., and Prain, G. (2018b). Gender Norms, Agency, and Innovation in Agriculture and Natural Resource Management: The GENNOVATE Methodology. Mexico: CIMMYT.

Petesch, P., Bullock, R., Feldman, S., Badstue, L., Rietveld, A., Bauchspies, W., et al. (2018c). Local normative climates shaping agency and agricultural livelihoods in sub-Saharan Africa. J. Gend. Agric. Food Secur. 3, 108-130. doi: 10.22004/ag.econ.293590

Petesch, P., Feldman, S., Elias, M., Badstue, L., Najiar, D., Rietveld, A., et al. (2018d). Community typology framed by normative climate for agricultural innovation, empowerment, and poverty reduction. J. Gend. Agric. Food Secur. 3, 131-157. doi: 10.22004/ag.econ.293592

Pircher, T., Almekinders, C. J. M., and Kamangwa, C. G. (2013). Participatory trials and farmers' social realities: understanding the adoption of legume technologies in a Malawian farmer community. Int. J. Agric. Sustain. 11, 252-263. doi: $10.1080 / 14735903.2012 .738872$

Poats, S. V., Schmink, M., and Spring, A. (1988). "Linking FSR/E and gender. An introduction," in Gender Issues in Farming Systems Research and Extension, eds S. V. Poats, M. Schmink, and A. Spring (Boulder, CO: Westview Press), 1-19. doi: $10.1201 / 9780429043895-1$
Rietveld, A., and Farnworth, C. R. (2018). Toward Gender-Responsive Banana Research for Development in the East-African Highlands. GENNOVATE Resources for Scientists and Research Teams. CDMX: CIMMYT.

Rietveld, A. M., Burg, M., and van der, Groot, J. C. J. (2020). Bridging youth and gender studies to analyse rural young women and men's livelihood pathways in Central Uganda. J. Rural Stud. 75, 152-163. doi: 10.1016/j.jrurstud.2020.01.020

Rogers, E. M. (2003). Diffusion of Innovations, 5th Edn. New York, NY: Free Press. Ronner, E., Descheemaeker, K., Almekinders, C. J. M., Ebanyat, P., and Giller, K. E. (2018). Farmers' use and adaptation of improved climbing bean production practices in the highlands of Uganda. Agric. Ecosyst. Environ. 261, 186-200. doi: 10.1016/j.agee.2017.09.004

Sørensen, P. (1996). Commercialization of Food Crops in Busoga, Uganda, and the Renegotiation of gender. Gend. Soc. 10, 608-628. doi: $10.1177 / 089124396010005007$

Stroud, A., and Kirkby, R. (2000). "The application of FSR to technology development," in FSR-Understanding Farming Systems ed M. Collinson (Wallingford: CABI Publishing), 95-129. doi: 10.1079/9780851994055.0095

Thompson, J., and Scoones, I. (2009). Addressing the dynamics of agri-food systems: an emerging agenda for social science research. Environ. Sci. Policy 12, 386-397. doi: 10.1016/j.envsci.2009.03.001

Tilmar, M. (2016). "Chapter 5: self-employed women's everyday innovations in East Africa," in Research Handbook on Gender and Innovation Research, eds G. A. Alsos, Ulla Hytti and Elisabet Ljunggren (Cheltenham: Edward Elgar), 91-106. doi: 10.4337/9781783478132.00011

van der Burg, M. (2019). "Change in the making: 1970s and 1980s building stones to gender integration in CGIAR agricultural research," in Gender, Agriculture and Agrarian Transformations, ed Sachs, E. Carolyn (London: Routledge), 35-57. doi: 10.4324/9780429427381-3

Zulu, L. C., Djenontin, I. N. S., Darkwah, A., Kamoto, J., Kampanje-Phiri, J., Fischer, G., et al. (2020). Realizing inclusive SAI: contextualizing indicators to better evaluate gender and intergenerational inequity in SAI processes and outcomes-cases from Southern and Western Africa. Int. J. Agric. Sustain. doi: $10.1080 / 14735903.2020 .1737356$

Conflict of Interest: The authors declare that the research was conducted in the absence of any commercial or financial relationships that could be construed as a potential conflict of interest.

The reviewer ER declared a shared affiliation with one of the authors, MB to the handling editor at time of review.

Publisher's Note: All claims expressed in this article are solely those of the authors and do not necessarily represent those of their affiliated organizations, or those of the publisher, the editors and the reviewers. Any product that may be evaluated in this article, or claim that may be made by its manufacturer, is not guaranteed or endorsed by the publisher.

Copyright (c) 2021 Rietveld and van der Burg. This is an open-access article distributed under the terms of the Creative Commons Attribution License (CC BY). The use, distribution or reproduction in other forums is permitted, provided the original author(s) and the copyright owner(s) are credited and that the original publication in this journal is cited, in accordance with accepted academic practice. No use, distribution or reproduction is permitted which does not comply with these terms. 